\title{
A Novel Approach in Problem-Solving Skills Using Flipped Classroom Technique
}

\section{Masila Alias', Zanaton H. Iksan', Aidah Abd Karim¹, Ahmad Mughis Hussein Mohd Nawawi², Siti Rabiatuladawiyyah Mohd Nawawi ${ }^{3}$}

\author{
${ }^{1}$ Faculty of Education, Universiti Kebangsaan Malaysia, Bangi, Malaysia \\ ${ }^{2}$ Faculty of Art, Computing and Creative Industry, Universiti Pendidikan Sultan Idris, Tanjung Malim, Malaysia \\ ${ }^{3}$ Faculty of Education, Universiti Teknologi MARA, Puncak Alam, Malaysia \\ Email: masila_alias@yahoo.com, zanaton.iksan@ukm.edu.my, eda@ukm.edu.my,mughishussein@gmail.com, \\ adawiyatun.edu@gmail.com
}

How to cite this paper: Alias, M., Iksan, Z. H., Karim, A. A., Nawawi, A. M. H. M., \& Nawawi, S. R. M. (2020). A Novel Approach in Problem-Solving Skills Using Flipped Classroom Technique. Creative Education, 11, 38-53.

https://doi.org/10.4236/ce.2020.111003

Received: December 3, 2019

Accepted: January 11, 2020

Published: January 14, 2020

Copyright $\odot 2020$ by author(s) and Scientific Research Publishing Inc. This work is licensed under the Creative Commons Attribution International License (CC BY 4.0).

http://creativecommons.org/licenses/by/4.0/

(c) (i) Open Access

\begin{abstract}
This quasi-experimental research aimed to determine the effectiveness of flipped classroom (FC) in improving problem solving skills (PSS). 120 secondary school science stream students were involved in this study. Pre- and post-PSS questionnaire were used as instruments and data were analysed using descriptive and inferential statistics. One-way ANOVA revealed that the mean difference between the study and control groups was 2.14, 2.68 and $0.58, P<0.05$. MANOVA analysis showed that there was an increase in sub-PSS, while Factorial MANOVA showed significant main and interactions effects. This proved that the FC approach had succeeded in improving PSS. Therefore, the MOE needs to provide professional training to teachers, school administrators need to reward the teachers, teachers need to sacrifice their time and money, parents need to give their trust and finally, students need to change their "spoon-feed" attitude to progress towards independent-learning. Problem-based learning needs to be integrated with FC.
\end{abstract}

\section{Keywords}

Flipped Classroom, Problem-Based Learning, Problem Solving Skill, Secondary School

\section{Introduction}

Creative and innovative initiatives in education to address the industrial revolution 4.0 are needed. This is because the technological revolution will change the way we live, the way we work and the way we interact (Schwab, 2016). The terms that are commonly discussed nowadays such as robot, Artificial Intelligence, 
disruptive innovation and technology make the education system seem outdated. Apparently, it is a requirement to prepare the students with several skills such as problem-solving skill specifically in solving complex problems which can be applied in their nature of work (Schwab, 2016). Whereas, the complex problems are measured based on the broadness of the range of conflict, the depth of the analysis and the information are needed (Schwab, 2016). However, the result of the past research shows that, the level of students' problem-solving skills is still considered as low and moderate (Johari et al., 2014; Norulbiah \& Effandi, 2016; Reddy \& Panacharoensawad, 2017) even supposing in IR 4.0. It is a need to emphasise the problem solving skills specifically in solving complex problems in learning and facilitation (L\&F). Therefore, it is an urgency that the pedagogical tools and learning approach need to align together with the rapid development of the technology. The efforts to provide students with relevant skills until they are working need to be intensified even if it is difficult to do (Syafiq, 2018). Through the right learning approach, the students' thinking can be stimulated (Gagné \& Briggs, 1974) even though they give various reasons for refusing to learn. Learning approaches adapted with modern technologies such as FC integrated with PSS are seen to solve this problem.

FC is a teaching approach that requires students to watch learning videos at home before engaging in the classroom activities (such as PBL) (Bergmann \& Sams, 2009; Bergmann \& Sams, 2012; Suhari et al., 2015). FC is used by educators to bring to life the traditional lecture classroom model into a more active learning (Keengwe et al., 2014). Many studies have proven that FC approach is better than conventional learning (Afidah, Fasihah, \& Rosmawati, 2017; Baris, 2017; Malto, Dalida, \& Lagunzad, 2018; Tutuncu \& Aksu, 2018; Sirakaya \& Ozdemir, 2018; Moreta, 2018). However, in Malaysia, this approach is still relatively new and has not been widely used in secondary school (Azlina et al., 2014).

Problem-based learning (PBL) is a learning approach solving real-world problems that are applicable to all areas of study (Azita, 2013; Ashraf, 2015; Rian, 2015; Gurses et al., 2015; Zuriawahida, 2016). However, there are some barriers to implementing a PBL at the secondary level, such as cognitive saturation (Noor Hisham, \& Lai, 2012), time constraints (Azita, 2013), student readiness and teacher competence in implementing it (Nor Amalina \& Zanaton, 2018).

Constructivism is the basic theory of FC and PBL which allows students to actively build their own knowledge or concept based on existing knowledge and experience (Arends, 1998). The theory of constructivism was born from the ideas of Piaget, Bruner and Vygotsky. Piaget's theory (1973) focused on the development of the individual's cognitive processes, namely cognitive processing in the form of schemes to explore the environment using a variety of senses, feelings, sensations and observations (Piaget, 1964) and eventually the learning process would occur if such learning could be adapted to the students (Evans, 1973). Information processing theory focuses on T\&L strategy for problem 
solving (Newell \& Simon, 1972). Cognitive load is divided into three namely intrinsic cognitive load, extraneous cognitive load and germane cognitive load (Kolloffel et al., 2009; Sweller, Van Merriënboer, \& Paas 1998). According to Noor Hisham and Lai (2012), the nature of the assignment or learning of cognitive load cannot be changed. However, the external and germane cognitive load can be changed and they are inversely proportional to each other. The more the extraneous load, the less the germane load. All of these theories, if properly applied, can produce a series of interesting T\&L and enhance students' PSS. The underlying theories of the study are the theory of constructivism, cognitive load theory and information processing theory.

Recent studies (Johari et al., 2014; Juhji, 2016; Hanisah et al., 2018) have shown that the application of constructivist learning theory helped students to master aspects of science such as science process skills and manipulative skills while improving student achievement. Sriadhi (2015) emphasized several theories including information processing theory in the construction of multimedia courseware in the electricity lesson. The results showed that the use of multimedia courseware has improved the achievement of memory scores and memory retention among students. The information processing model assumed that human memory is just like a computer (Azizi et al., 2005). The findings of the study by Siti Suhaila (2015) showed that the use of visual animation multimedia courseware can help improve Mathematics achievement in the classroom especially if it doesn't require calculation.

Learning videos for flipped classroom approaches are effective in improving learning (Alsancak \& Selçuk, 2018; Malto et al., 2018; Nurhan \& Meral 2018; Moreta, 2018). Learning videos captured students' attention to the content presented. Subsequently, there was an increase in the time of problem-solving activities with the teachers because the content was conveyed through learning videos at home (Bergmann \& Sams, 2012). Students can directly ask questions about concepts that are not well understood and be able to perform problem solving activities well. This is because students can ask their teachers and peers directly.

Most students who are not interested in science will say science is a subject that is burdensome and difficult to understand (Meerah, 1998). However, for students who are interested in science, they considered studying science as a meaningful learning process (Chiapetta et al., 1998). Therefore, this study is to look at both groups of students whether they are interested or not interested in science, could they still master these lessons through a FC approach that is integrated with the PBL. Students who are given the opportunity to actively develop knowledge by comparing new information with their existing knowledge (Driver et al., 2014) will surely find something meaningful themselves. Generally, a student's existing knowledge of a science concept is contrary to a scientific idea, so students should be guided to learn the correct concept, based on the accepted evidence and belief and thus motivate them to change their initial thinking (Jones, 1998). 
Learning strategies and techniques for transferring scientific information to educational information (Khalib, 2002) requires knowledge and high level of creativity (Saint \& Robert, 1976). Therefore, appropriate learning methods need to be selected and implemented effectively (Mok, 2008; Phang et al., 2014). It is time to shift the focus of our students from "more hours for learning" to "quality learning time" (OECD, 2018). Students' learning from the textbook and passive learning needs to be refined. Textbooks can be refined with video lessons and classroom activities can be enhanced through PBL. Cognitive burden for novice students (Noor Hisham \& Lai, 2012) can be reduced through video learning before PBL activities begin in the classroom. The process of rebuilding concepts and shaping scientific thinking takes a long time. With the learning videos, students can repeat the learning at their own pace (Bergmann \& Sams, 2012). This way, a broad lesson plan can be developed to ensure that the process of conceptualization and scientific thinking takes place both inside and outside the classroom within a set period of lesson.

Previous studies that addressed similar issues have prompted the researchers to conduct a study to produce students who are more confident and able to achieve high-impact PSS. The aim of this research is to study the effectiveness of the use of FC-PBL module in improving the problem-solving skills by specializing the activities at home by watching educational videos while the classroom activities using problem-based learning approach. The effectiveness of this module is addressed through the following research questions and null hypothesis.

1) Are there any significant difference in the mean of pre and post-PSS scores between the FC-PBL, PBL and conventional groups?

2) Are there any main effect on the groups and time and the interaction effect on the groups and time towards the sub-PSS?

Ho1: There are no significant differences in the mean of pre and post-PSS scores between the FC-PBL, PBL and conventional groups.

Ho2: There are no significant main effects on groups and time and the interaction effects of groups and time on the sub-PSS.

\section{Methods}

The study used a quasi-experimental method involving 120 secondary school science students. This method is suitable for this research because the selection of each study group used existing groups, which means that it does not involve random selection (Cook \& Campbell, 1979). This is to prevent the learning and facilitation (L\&F) of the existing class being interrupted (Creswell, 2002). The study group and control group were selected based on their corresponding characteristics (Chua, 2006). Sample criteria were determined by the equivalent level of basic chemistry knowledge, urban area, national secondary school, form four science stream, taught by experienced teachers and have internet access.

The sample of the research are chosen from form four science stream students of national secondary school is because, based on the analysis of the SPM ex- 
amination result for the year 2015-2018 in Petaling Perdana, the national secondary school students' achievement in chemistry subject in is still consider as moderate (SMK Harian PPDPP 2015-2018). This is relateable with the moderate and low ability in problem solving skills of the students in order to achieve the understanding, application and analysis level (LPM, 2017). The result gained by this research is in line with the research BPK (2019) which shows that students are inexperienced and do not like to study problems. The need for learning approach that can overcome this problem is significant. Many research related to problem-based learning PBL (Azita, 2013; Ashraf, 2015; Rian, 2015; Ahmet et al., 2015; Zuriawahida, 2016) and flipped classroom FC (Afidah, Fasihah, \& Rosmawati, 2017; Baris, 2017; Malto, Dalida, \& Lagunzad, 2018; Tutuncu \& Aksu, 2018; Sirakaya \& Ozdemir, 2018; Moreta, 2018) can increase the PBS. However, the implementation of authentic PBL has taken a long time (Azita, 2013) and the FL approach has not been practiced yet in national secondary school (Azlina et al., 2014). In addition, the unfamiliar attitude of students with the absence of teachers (Hanim \& Nurol Aleyzan, 2017) and the findings of the study also showed that the student-teacher group performed better than the non-teacher group (Mustafa, 2016) encouraging researchers to integrate both of these two approaches to overcome the PSS problems of national secondary school. National secondary school students in urban areas were selected because preliminary analysis found that internet access, computer ownership and mobile phones were not a problem in the study that required students to complete the learning videos provided before learning and facilitate (L\&F) in school.

The research begins with an initial study followed by the construction of the FC-PBL module using the ADDIE model, pilot study and final evaluation. Through preliminary analysis, it was found that the most difficult topic was Salt (51.25\%). This finding is in line with previous findings (Rosnaini \& Norsiati, 2008; Lee \& Kamisah, 2012). Preliminary analysis also found that the average student who liked the problem-solving method in the classroom was $64(80 \%)$ and the average student who liked the FC method was 66.7 (83.3\%). Researcher provided two types of activity design: home activity design (learning video design) and school activity design (PBM design). Researcher used "PowToon" for video production because the video can be kept online and does not require high quality device. Researchers have set HD (high defenision) 480 because its small size makes it easier for Middle School students to use whatsapp better than other social media to downloads video. The FC-PBL module is a printed module that contains learning videos. Once completed, the module is pilot tested and the actual study is performed as soon as the expert comment correction is implemented. The effectiveness of the FC-PBL module was implemented based on a quasi-experimental study design.

The quasi-experimental design of this study is shown in Table 1 . The pre-test was used in this study to investigate whether there were similarities between treatment groups and control groups as well as for statistical controls. The steps 
Table 1. Pre-post-test design.

\begin{tabular}{cccc}
\hline Group & Pre-test & L\&F Strategy & Post-test \\
\hline FC-PBL group & $\mathrm{O}_{1}$ & FC-PBL & $\mathrm{O}_{2}$ \\
PBL group & $\mathrm{O}_{3}$ & PBL & $\mathrm{O}_{4}$ \\
Conventional group & $\mathrm{O}_{5}$ & Conventional & $\mathrm{O}_{6}$ \\
\hline
\end{tabular}

involved are: 1) identifying control groups and treatment groups; 2) conducting a pre-test on all respondents; 40 students per group; 3) apply constructivism-based teaching strategies to treatment groups and traditional teaching strategies to control groups; 4) performing the post-test to all respondents; and 5) collect and analyse data.

In this design, $\mathrm{O}_{1}$ and $\mathrm{O}_{3}$ represent the treatment group while $\mathrm{O}_{5}$ represent the control group before the intervention. $\mathrm{O}_{2}$ and $\mathrm{O}_{4}$ represented the treatment group after the intervention and $\mathrm{O}_{6}$ represented the control group after the intervention. The teaching method given to the respondents was flipped classroom problem-based learning (FC-PBL), PBL and conventional learning. All three groups were given a pre- test (intervention). At the end of the study, all three groups were given a post-test consisting of a PSS questionnaire.

Pre and post PSS questionnaire instruments were used and data were analysed using Statistical Packages for Social Sciences (SPSS) Version 23.0 software. The PSS questionnaire instrument consist of 31 items and the Rasch model reliability index and item isolation index (Wright \& Stone, 1999; Mohd \& Ahmad, 2014) obtained was 0.83 and 0.76 . According to Fisher (2007) the sample reliability index of 0 to 1 is very good. One-way ANOVA, Manova and $3 \times 2$ factorial MANOVA were used to analyse the data to see the effectiveness of FC in improving PSS for the secondary school students.

The FC-PBL group is taught using the flipped classroom approach and problem-based learning used the FC-PBL module. In this group, teachers will be provided with daily lesson plans and FC-PBL modules. The PBL groups were taught using only the problem-based learning approaches. In this group, teachers were provided with PBL daily lesson plans. Finally, for conventional groups, they were taught using conventional methods. Teachers were provided with a conventional daily lesson plan. The rationale for creating these three groups is to enable researchers to gauge the effectiveness of an innovative PBL with flipped classroom approach. The presence of the second treatment group (PBL group) acts as a reverse treatment (Cook \& Campbell, 1979). The second treatment added to the variety of L\&F techniques that teachers could consider. This group also served as a control over the effectiveness of the FC-PBL module by proving that in the event of an increase in salt performance, PSS and KPTK, the increase is due to the innovative PBL approach and was not due to the PBL.

Table 2 shows the comparison of class schedule for Conventional, PBL, and FC-PBL classes which was adapted to the daily allocation of L\&F in SMK for this study. 
Table 2. Comparison of conventional, PBL and FC-PBL class times.

\begin{tabular}{|c|c|c|c|c|c|}
\hline \multicolumn{2}{|c|}{ Conventional Classroom } & \multicolumn{2}{|l|}{ PBL } & \multicolumn{2}{|l|}{ FC-PBL } \\
\hline Activity & Time & Activity & Time & Activity & Time \\
\hline Set induction & $5 \mathrm{~min}$ & $\begin{array}{l}\text { Set Induction and } \\
\text { Distribution group }\end{array}$ & $5 \mathrm{~min}$ & Set induction & $5 \mathrm{~min}$ \\
\hline $\begin{array}{c}\text { Conducting the review of } \\
\text { homework }\end{array}$ & $15 \mathrm{~min}$ & $\begin{array}{c}\text { Implementation of } \\
\text { PBL activities }\end{array}$ & $40 \mathrm{~min}$ & $\begin{array}{l}\text { Q\&A for the video } \\
\text { watched }\end{array}$ & $10 \mathrm{~min}$ \\
\hline Teaching new content & $30 \mathrm{~min}$ & Evaluation & $15 \mathrm{~min}$ & $\begin{array}{l}\text { Guide individual } \\
\text { work/laboratory } \\
\text { activities }\end{array}$ & $45 \mathrm{~min}$ \\
\hline $\begin{array}{c}\text { Guide individual } \\
\text { work/laboratory activities }\end{array}$ & $10 \mathrm{~min}$ & & & & \\
\hline Homework & 2 hours & Homework & 2 hours & Homework & 2 hours \\
\hline
\end{tabular}

According to Table 2, homework for the conventional group means exercise provided by the teacher to students to be completed at home and submitted in the next class or to review the lesson. While homework for PBL classes refers to any problem-solving exercises that are not solved in the classroom, they need to be completed at home and submitted in the next class or review the lessons. For the FC-PBL class, homework means that students have to watch the learning video and complete the guided notes for the next subject or review the lesson. This is to ensure that an equal allocation of time is obtained by each group and individual involved in the study. Teachers must use the six lesson plans provided to ensure that the L\&F complies with the desired procedure. During the research period, teachers and students were asked not to participate in any school program so that the study could be carried out according to plan.

\section{Results and Discussion}

One-way ANOVA tests were used to see if there were significant differences between pre and post-test scores between groups. Manova, on the other hand, looked at the PSS results, specifically on the sub-PSS. One-way ANOVA test results are presented in Table 3 and Table 4. There was no significant difference in the mean of pre-PSS questionnaire scores between the FC-PBL, PBL and conventional groups before the intervention, showed that students had the same PSS. On the other hand, the post-questionnaires showed significant differences in the mean of post-PSS scores between the FC-PBL, PBL and conventional groups.

Table 5 showed the results of the Scheffe Post Hoc test for post-PSS between groups.

The Scheffe Post Hoc results in Table 5 showed that there was a significant difference in the mean of post-PSS scores between groups using the FC-PBL module and group using PBL learning with a mean difference $=-2.14$ and sig $=$ $0.000(P<0.05)$. There was a significant difference in the mean of post-PSS 
Table 3. One-way ANOVA test results for the pre-PSS between groups.

\begin{tabular}{|c|c|c|c|c|c|}
\hline Salt Achievement Test & Total squared & Degree of freedom (df) & Mean squared & $\mathrm{F}$ & Sig. \\
\hline Between Groups & 0.034 & 2 & 0.017 & 0.124 & 0.884 \\
\hline In Group & 16.035 & 117 & 0.137 & & \\
\hline Total & 16.069 & 119 & & & \\
\hline
\end{tabular}

Table 4. One-way ANOVA test results between groups of PSS post.

\begin{tabular}{cccccc}
\hline KMM & Total squared & Degree of freedom (df) & Mean squared & F & Sig. \\
\hline Between Groups & 161.200 & 2 & 80.600 & 505.000 & 0.000 \\
In Group & 18.674 & 117 & 0.160 & & \\
Total & 179.874 & 119 & & & \\
\hline
\end{tabular}

Table 5. Scheffe Post Hoc Test Results Post PSS between groups.

\begin{tabular}{ccccc}
\hline (I) Group & (J) Group & Mean Difference (I-J) & Std. Error & Sig. \\
\hline \multirow{2}{*}{ FC-PBL group } & PBL group & $-2.14032^{*}$ & 0.08933 & 0.000 \\
& Conventional group & $-2.68548^{*}$ & 0.08933 & 0.000 \\
\multirow{2}{*}{ PBL group } & FC-PBL group & $2.14032^{*}$ & 0.08933 & 0.000 \\
& Conventional group & $-0.54516^{*}$ & 0.08933 & 0.000 \\
Conventional group & FC-PBL group & $2.68548^{*}$ & 0.08933 & 0.000 \\
& PBL group & $0.54516^{*}$ & 0.08933 & 0.000 \\
\hline
\end{tabular}

scores between groups using the FC-PBL module and groups using the conventional learning with the mean differences of -2.68 and sig $=0.000(P<0.05)$. Finally, there was a significant difference in the mean of post-PSS scores between groups using PBL learning and groups using conventional learning with the mean difference $=0.54$ and sig $=0.000(P<0.05)$.

The effect size was obtained by computing the Eta squared as follows:

Eta squared $=$ Sum of squares between groups/Total sum of squares

$$
=161.200 / 179.874=0.896
$$

Table 6 shows the results of the MANOVA analysis for the sub-PSS post-test while Table 7 shows the results of the Scheffe post hoc test.

According to Table 6, there were significant differences in planning, evaluation and expectation skills between the FC-PBL, PBL and conventional groups. Table 7 shows that the mean difference of planning skills between the FC-PBL and PBL groups was $-2.243, P<0.005$; between the FC-PBL and conventional groups, the mean difference was $-2.666, P<0.005$ and between the PBL and conventional groups, the mean difference was $-0.423, P<0.005$. Furthermore, the evaluation skills between the FC-PBL and PBL groups, the mean difference = $-2.14, P<0.005$; between the FC-PBL group and conventional, the mean difference $=-2.705, P<0.005$. Between the PBL and conventional groups, there was also a significant mean difference between the PBL and conventional groups 
Table 6. MANOVA analysis for the sub-PSS post-test.

\begin{tabular}{ccccccccc}
\hline $\begin{array}{c}\text { The dependent } \\
\text { variable }\end{array}$ & Group & Mean & $\begin{array}{c}\text { Std. } \\
\text { deviation }\end{array}$ & $\begin{array}{c}\text { Total squared } \\
\text { type III }\end{array}$ & Df & $\begin{array}{c}\text { Mean } \\
\text { Square }\end{array}$ & F & Sig \\
\hline \multirow{2}{*}{ Planning } & FC-PBL & 1.32 & 0.434 & & & & & \\
& PBL & 3.56 & 0.557 & 164.24 & 2 & 82.12 & 305.17 & 0.00 \\
& Conventional & 3.98 & 0.555 & & & & & \\
\multirow{5}{*}{ Evaluate } & FC-PBL & 1.34 & 0.376 & & & & & \\
& PBL & 3.48 & 0.505 & 162.88 & 2 & 81.44 & 380.85 & 0.00 \\
& Conventional & 4.05 & 0.495 & & & & & \\
Expect & FC-PBL & 1.34 & 0.396 & & & & & \\
& PBL & 3.37 & 0.427 & 156.92 & 2 & 78.46 & 375.21 & 0.00 \\
& Conventional & 4.03 & 0.536 & & & & & \\
\hline
\end{tabular}

Table 7. Results of the Scheffe post hoc test.

\begin{tabular}{|c|c|c|c|c|c|}
\hline $\begin{array}{l}\text { The dependent } \\
\text { variable }\end{array}$ & (I) group & (J) group & Min difference (I-J) & $\begin{array}{c}\text { Standard } \\
\text { error }\end{array}$ & Sig. \\
\hline \multirow{6}{*}{ Planning } & \multirow{2}{*}{ FC-PBL } & PBL & $-2.243^{*}$ & 0.11599 & 0.000 \\
\hline & & Conventional & $-2.666^{*}$ & 0.11599 & 0.000 \\
\hline & \multirow{2}{*}{ PBL } & FC-PBL & $2.243^{*}$ & 0.11599 & 0.000 \\
\hline & & Conventional & $-0.423^{\star}$ & 0.11599 & 0.001 \\
\hline & \multirow{2}{*}{ Conventional } & FC-PBL & $2.666^{*}$ & 0.11599 & 0.000 \\
\hline & & PBL & $0.423^{*}$ & 0.11599 & 0.001 \\
\hline \multirow{6}{*}{ Evaluate } & \multirow{2}{*}{ FC-PBL } & PBL & $-2.140^{*}$ & 0.10340 & 0.000 \\
\hline & & Conventional & $-2.705^{\star}$ & 0.10340 & 0.000 \\
\hline & \multirow{2}{*}{ PBL } & FC-PBL & $2.140^{*}$ & 0.10340 & 0.000 \\
\hline & & Conventional & $-0.565^{\star}$ & 0.10340 & 0.000 \\
\hline & \multirow{2}{*}{ Conventional } & FC-PBL & $2.705^{*}$ & 0.10340 & 0.000 \\
\hline & & PBL & $0.565^{\star}$ & 0.10340 & 0.000 \\
\hline \multirow{6}{*}{ Expect } & \multirow{2}{*}{ FC-PBL } & PBL & $-2.028^{\star}$ & 0.10225 & 0.000 \\
\hline & & Conventional & $-2.688^{\star}$ & 0.10225 & 0.000 \\
\hline & \multirow{2}{*}{ PBL } & FC-PBL & $2.028^{*}$ & 0.10225 & 0.000 \\
\hline & & Conventional & $-0.660^{*}$ & 0.10225 & 0.000 \\
\hline & \multirow{2}{*}{ Conventional } & FC-PBL & $2.688^{*}$ & 0.10225 & 0.000 \\
\hline & & PBL & $0.660^{*}$ & 0.10225 & 0.000 \\
\hline
\end{tabular}

${ }^{\star}$ Significant on the level 0.05 .

with the mean difference $=-0.565$ and sig $=0.000, P<0.005$. Lastly, expectation skills between the FC-PBL and PBL groups, the mean difference $=-2.028, P<$ 0.005 . Between the FC-PBL and conventional groups, the mean difference $=$ $-2.688, P<0.005$. Between the PBL and conventional groups the mean differ- 
ence $=-0.660, P<0.005$. Lower mean values are the better one based on Likert values 1 was for "strongly agree" while" 5 was" strongly disagree".

Finally, to see the main effects (groups and test time) and interaction effects (group * test time) on the sub-PSS, $3 \times 2$ factorial MANOVA was conducted and the results of the analysis are shown in Table 8.

Based on Table 8, there was a significant main effect of independent group variables $[\mathrm{F}(6,464.00)=66.88], P<0.05]$ on sub-PSS. Furthermore, there was a significant main effect of the independent variable time $[\mathrm{F}(3,232.00)=273.58]$, $P<0.05$ ] on planning, evaluation and expectation skills and finally, there was a significant effect of group interaction ${ }^{*}$ test time $\left.\mathrm{F}(6,464.00)=65.24\right], P<0.005$ for the dependent variables namely the planning, evaluation and expectation skills.

Table 9 shows the results of the Test of Between-subject effects.

According to Table 9, the in overall sub-PSS planning and test time contributed $83.9 \%$, and the sub-PSS evaluation skill was $85.8 \%$ and the sub-PSS expectation skill was $86.5 \%$. This means that the interaction between groups and test time contributed to a change in the sub-PSS of planning, evaluation and expectation of a student. The pairwise comparison result for the group showed for the planning, evaluation and expectation skills of the FC-PBL group were higher than the PBL and conventional groups. Furthermore, the pairwise comparison test for time also confirmed that time was a factor in all subgroups of students.

Table 8 . The results of the sub-PSS, $3 \times 2$ factorial MANOVA.

\begin{tabular}{cccccc}
\hline Effect & Wilks' Lambda & F value & df Hypothesis & df Error & Sig. \\
\hline Group & 0.288 & $66.884^{\mathrm{b}}$ & 6.000 & 464.000 & 0.000 \\
Time & 0.220 & $273.586^{\mathrm{b}}$ & 3.000 & 232.000 & 0.000 \\
Group ${ }^{*}$ Time & 0.294 & $65.249^{\mathrm{b}}$ & 6.000 & 464.000 & 0.000 \\
\hline
\end{tabular}

Table 9. Test of Between-subject effects sub-PSS.

\begin{tabular}{ccccccc}
\hline \multirow{2}{*}{ Source } & $\begin{array}{c}\text { The dependent } \\
\text { variable }\end{array}$ & $\begin{array}{c}\text { Total squared } \\
\text { type III }\end{array}$ & df & $\begin{array}{c}\text { Mean } \\
\text { squared }\end{array}$ & F & Sig. \\
\hline Planning & 82.329 & 2 & 41.164 & 184.191 & 0.000 \\
Evoup & Evaluate & 83.265 & 2 & 41.633 & 214.517 & 0.000 \\
& Expect & 78.264 & 2 & 39.132 & 215.513 & 0.000 \\
Planning & 114.314 & 1 & 114.314 & 511.499 & 0.000 \\
& Evaluate & 118.582 & 1 & 118.582 & 611.009 & 0.000 \\
& Expect & 121.268 & 1 & 121.268 & 667.861 & 0.000 \\
& Planning & 81.911 & 2 & 40.956 & 183.256 & 0.000 \\
Group ${ }^{*}$ Time & Evaluate & 79.664 & 2 & 39.832 & 205.240 & 0.000 \\
& Expect & 78.749 & 2 & 39.374 & 216.846 & 0.000 \\
\hline
\end{tabular}

${ }^{\mathrm{a}} \mathrm{R}$ Squared $=0.842$ (Adjusted R Squared $=0.839$ ); ${ }^{\mathrm{b}} \mathrm{R}$ Squared $=0.861$ (Adjusted $\mathrm{R}$ Squared $=0.858$ ); ${ }^{\mathrm{c}} \mathrm{R}$ Squared $=0.868$ (Adjusted R Squared $=0.865$ ). 
The post-sub-PSS superseded the pre-sub-PSS significantly in the planning, evaluation and expectation aspects.

In this study, the PBL and FC-based teaching process presented new and challenging learning for students in the form of self-directed learning using today's technology through learning videos that required the sacrifice of teachers and students outside of school hours and required students to solve problems under the guidance of teachers and classmates, were finally able to draw the students' attention and interest into learning. This study was conducted regarding students' readiness to learn using online or offline videos. Through the FC approach, students' PSS improved as students were more comfortable and more confident in facing the challenges of PBL in schools after watching the video. They can showcase their talents during problem solving and presentation sessions. Video watching activities at home provided early-stage knowledge and keep students more engaged in learning and able to spend more time with friends and teachers (Bergmann \& Sam, 2009; Bergmann \& Sam, 2012). This is in line with the findings of the previous study (Afidah, Fasihah, \& Rosmawati, 2017; Baris, 2017; Malto, Dalida, \& Lagunzad, 2018; Tutuncu \& Aksu, 2018; Sirakaya \& Ozdemir, 2018; Moreta, 2018; Alsancak \& Selçuk, 2018; Malto et al., 2018; Nurhan \& Meral, 2018). The PBL activities which are the special activities of this study make the students fully responsible for their learning (Morgan \& Williams, 2010; Ashraf, 2015; Azita \& Zuriawahida, 2016; Zuriawahida, 2016).

The application of the constructivism theory and information technology in the FC-PBL is very helpful to students in improving PSS. When solving problems, students can actively develop knowledge or concepts. They solved this collaboratively and shared information obtained from the learning video before the lesson. Students were able to perform group activities better in class than in passive and one-way conventional methods. This is in line with what was stated by Arends (1998) and in line with previous research findings (Butt, 2014; Johari et al., 2014; Juhji, 2016; Zanariah, 2017; Hanisah et al., 2018). Students were also able to perform better group activities in the classroom than the authentic PBL method as they had been provided with existing knowledge. Learning approaches that used technology and information such as FC helped enhance students' existing knowledge (Salih et al., 2006) and the PBL approach that provides examples of problem solving (Noor Hisham \& Lai, 2012; Sweller, Van Merriënboer, \& Paas 1998) reduced students' cognitive load. This can improve students' PSS.

\section{Implications and Recommendations}

As stated in earlier part of writing, the studied FC-PBL group used modules specially built for the purpose of this study. Therefore, the findings of this study have theoretical and practical implications. Theoretically, FC by Bergmann and Sams (2012) need to be modified by adding guided notes while watching videos. While Wee's (2004) PBL needs to be modified by incorporating video viewing activities before the PBL class is conducted and group division is performed on 
the first activity only. If PBL that being use in Temasek Polytechnic in Singapore initiated activity with group formation followed by real world problem-solving activity, FC-PBL initiated activity by watching home learning videos before problem solving activity in class. Learning videos as early preparation have proven to enhance student achievement, PSS and SDLR. This study gives implications for teachers, administrators, curriculum makers and the Ministry of Education in designing student-centered (L\&F) materials and ICT culture that in line with the national aspirations. With ample financial resources and resources, the FC-PBL produced is certainly of better quality. Parents are exposed to the importance of learning at their fingertips. As such, the use of FC-PBL in learning will surely produce more fruitful results if carried out at all levels of the school involving all the subjects and Units in the school.

The suggestions are as follows:

1) Further research to empirically test the customized FC and PBL.

2) Engage more respondents with diverse backgrounds, which include socio-economy, ability, age, gender and bigger sample size.

\section{Conclusion}

From the research conducted, the FC-PBL treatment group showed the best PSS and sub-PSS achievement. Group and time are factors contributing to the change in the planning, evaluation and expectation skills of a student. The findings of this study have theoretical and practical implications. The findings of the study help the students to improve their PSS and to make it easier and more effective for the teachers to deliver lessons in limited time. Watching a learning video at home required a lot of enthusiasm and desire from the individual student as well as the parents and guardians. The PBL approach is a key focus of the KSSM and should be implemented by every educator during L\&F. Therefore, if this effort is supported by all parties, then integrating the FC approach with the PBL will solve the problem of time constraints in implementing the PBL in daily schools.

\section{Acknowledgements}

This research was partially supported by Faculty of Education, Universiti Kebangsaan Malaysia Fund under the Dana Penyelidikan FPEND GG-2019-047.

\section{Conflicts of Interest}

The authors declare no conflicts of interest regarding the publication of this paper.

\section{References}

Afidah, A. M., Fasihah, A., \& Rosmawati, A. R. (2017). Aplikasi video pembelajaran atas talian: Impak kepada kualiti pembelajaran dan pengajaran. eProceeding National Innovation and Invention Competition Through Exhibition (iCompEx'17). 
https://upikpolimas.edu.my/conference/index.php/icompex/icompex17/paper/viewFile $/ 115 / 111$

Ahmet, G., Cetin, D., \& Esen, G. (2015). Teaching of the Concept of Entalpy Using Problem Based Learning Approach. Procedia-Social and Behavioral Sciences, 197, 2390-2394.

https://www.researchgate.net/publication/282492475_Teaching_of_the_Concept_of_E nthalpy_Using_Problem_Based_Learning_Approach https://doi.org/10.1016/j.sbspro.2015.07.298

Alsancak, S., \& Selçuk, Ö. (2018). The Effect of a Flipped Classroom Model on Academic Achievement, Self-Directed Learning Readiness, Motivation and Retention. Malaysian Online Journal of Educational Technology, 6, 76-91.

Arends, R. I. (1998). Learning to Teach (Edisi ke-4). Boston, MA: McGraw Hill.

Ashraf, F. A. K. (2015). The Effect of Problem Based Learning Instruction on Learning Genetics and Inheritance Unit in Qatari Schools. Doctoral Dissertation, Malaysia: Universiti Kebangsaan Malaysia.

Azita, A. (2013). Kerangka Modul Bahasa C Menggunakan Pendekatan Model Integrasi Pembelajaran Berasaskan Masalah Dan Pendidikan Berteraskan Kompetensi. Doctoral Dissertation, Malaysia: Universiti Teknologi Malaysia.

Azita, A., \& Zuriawahida, Z. (2016). Keberkesanan kaedah pembelajaran berasaskan masalah dalam meningkatkan kemahiran menyelesaikan masalah dalam kalangan pelajar. Jurnal Pemikir Pendidikan, 7, 113-136.

Azizi, Y., Noordin, Y., \& Zurihanmi, Z. (2005). Psikologi Kognitif. Skudai: Penerbit Universiti Teknologi Malaysia.

Azlina, A. R., Baharuddin, A., Hasnah, M. A., Norasykin, M. Z., \& Zaleha, A. (2014). Flliped Classroom Dalam Konteks Malaysia. Konvension Antarabangsa Jiwa Pendidik 2014. https://www.slideshare.net/morkie/flipped-classroom-dalamkonteksmalaysia1

Baris, S. (2017). The Effectiveness of a Technology-Enhanced Flipped Science Classroom. Journal of Educational Computing, 55, 471-494. https://doi.org/10.1177/0735633116671325

Bergmann, J., \& Sams, A. (2009). Remixing Chemistry Class: Two Colorado Teachers Make Vodcast of Their Lectures to Free up Class Time for Hands-on Activities. Learn ing and Leading with Technology, 36, 22-27.

Bergmann, J., \& Sams, A. (2012). Flip Your Classroom: Reach Every Student in Every Class Every Day. International Society for Technology in Education (ISTE).

BPK (2019). Taklimat Umum Kursus Orentasi KSSM Kimia Tingkatan 4 dan 5. https://www.coursehero.com/file/37435402/0-Pendahuluan-Kursuspptx/

Butt, A. (2014). Student Views on the Use a Flipped Classroom Approach: Evidence from Australia. Business Education \& Accreditation, 6, 33-44.

Chiapetta, E. L., Koballa, T. R., \& Collette, A. T. (1998). Science Instruction in the Middle and Secondary Schools. Prentice, NJ: Prentice Hall.

Chua, Y. P. (2006). Asas Statistik Penyelidikan 1. Shah Alam: Mc Graw-Hill sdn.

Cook, T. D., \& Campbell, D. T. (1979). Quasi-Experimentation: Design and Analysis Issues for Field Setting. Chicago, IL: Rand McNully.

Creswell, J. W. (2002). Educational Research: Planning, Conducting, and Evaluating Quantitative (pp. 146-166). Upper Saddle River, NJ: Prentice Hall.

Driver, R., Squires, A., Rushworth, P., \& Wood-Robinson, V. (2014). Making Sense of Secondary Science: Research into Children's Ideas. London: Routledge. 
https://doi.org/10.4324/9781315747415

Evans, R. (1973). Jean Piaget: The Man and His Ideas. New York: E. P. Dutton \& Co., Inc.

Fisher, W. (2007). Rating Scale Instrument Quality Criteria. Rasch Measurement Transactions, 21, 1095.

Gagné, R., \& Briggs, L. J. (1974). Principles of Instructional Design. New York: Holton, Rinehart \& Winston.

Gurses, A., Dogar, C., \& Geyik, E. (2015). Teaching of the Concept of Enthalpy Using Problem Based Learning Approach. Procedia-Social and Behavioral Sciences, 197, 2390-2394. https://doi.org/10.1016/j.sbspro.2015.07.298

Hanim, P., \& Nuorol Aleyzan, G. (2017). Pelaksanaan pembelajaran Berpusatkan pelajar di Jabatan Perdagangan. http://www.pmm.edu.my/zxc/pustaka/writing/pmmfasa8/P.ILMIAH\%202017-4.pdf

Hanisah, Y., Suzilaeli, M. S., \& Ainor, I. M. (2018). Kajian Penguasaan Kemahiran Amali Sains Dan Hubungannya Dengan Pencapaian Akademik Bagi Kursus Engineering Science Dalam Kalangan Pelajar Di Polisas. National Innovation and Invention Competition through Exhibition (iCompEx'18).

Johari, M., Putu Arnyana, I. B., \& Nyoman Setiawan, I. G. A. (2014). Pengaruh Pembelajaran Pendekatan Saintifik Terhadap Hasil Belajar Biologi dan Keterampilan Proses Sains Siswa MA Mu'allimat NW Pancor Selong Kabupaten Lombok Timur Nusa Tenggara Barat. e-Journal Program Pascasarjana Universitas Pendidikan Ganesha, 4, $1-12$.

Jones, L. (1998). Engaging Children in Science. Prentice, NJ: Prentice Hall.

Juhji, J. (2016). Peningkatan Keterampilan Proses Sains Siswa Melalui Pendekatan Inkuiri Terbimbing. Jurnal Penelitian dan Pembelajaran IPA, 2, 58-70.

Keengwe, J., Onchwari, G., \& Oigara, J. N. (2014). Promoting Active Learning through the Flipped Classroom Model. Information Science Reference. https://doi.org/10.4018/978-1-4666-4987-3

Khalib, A. L. (2002). Memindahkan Maklumat Saintifik Kepada Maklumat Pendidikan: Apa Keterampilan Yang Perlu Ada? Jurnal Kesihatan Masyarakat, 8, 29-33.

Kolloffel, B., Eysink, T., de Jong, T., \& Wilhelm, P. (2009). The Effects of Representation Format on Learning Combinatories from an Interactive Computer. Instructional Science, 37, 503-515. https://doi.org/10.1007/s11251-008-9056-7

Lee, T. T., \& Kamisah, O. (2012). Penggunaan modul multimedia interaktif dengan agen pedagogi dalam pembelajaran elektrokimia: Kesan terhadap pemahaman konsep dalam elektrokimia (Application of Interactive Multimedia Module with Pedagogical Agent in the Learning of Electrochemistry: Effects on Conceptual Understanding in Electrochemistry). Sains Malaysiana, 41, 1301-1307.

LPM (2017). Kupasan mutu jawapan kimia 2 2017. Lembaga Peperiksaan Malaysia. http://lp.moe.gov.my/images/bahan/spm/KMJ/KMJ_SPM_2017/KIMIA\%202\%20(4541 2).pdf

Malto, G. A. O., Dalida, C. S., \& Lagunzad, C. G. B. (2018). Flipped Classroom Approach in Teaching Biology: Assessing Students' Academic Achievement and Attitude Towards Biology. KnE Social Sciences, 3, 540-554. https://doi.org/10.18502/kss.v3i6.2403

Meerah, T. S. M. (1998). Dampak penyelidikan pembelajaran sains terhadap perubahan kurikulum. Bangi: Penerbit Universiti Kebangsaan Malaysia.

Mohd, E. E. M. M., \& Ahmad, Z. K. (2014). Mengenal pasti cabaran pelajar politeknik di Malaysia Menerusi Model Rasch. Journal of Quality Measurement and Analysis, 10, 59-74. 
Mok, S. S. (2008). Psikologi Pendidikan untuk Pengajaran \& Pembelajaran. Ipoh, Malaysia: Penerbitan Multimedia Sdn.

Moreta, A. (2018). Flipped classroom dalam pembelajran lisan (pp. 42-57). Seminar Bahasa Melayu 2018.

Morgan, J., \& Williams, B. (2010). Process Education Best Practices for Teaching Open-Ended Problem Solving in a Project Context. International Journal of Process Education, 2, 35-49.

Mustafa (2016). Kehadiran Guru, Tahap Pencapaian Pelajar, Kemahiran Pembelajaran Dan Sikap Dalam Pembelajaran Sains Fizik Melalui Kaedah Pembelajaran Berbantukan Komputer. Tesis Dr. Fal, Kedah, Malaysia: Universiti Utara Malaysia. http://www.malrep.uum.edu.my/rep/Record/my.uum.etd.6031

Newell, A., \& Simon, H. A. (1972). Human Problem Solving. Englewood Cliffs, NJ: Prentice-Hall.

Noor Hisham, J., \& Lai, C. S. (2012). Beban Kognitif Dalam Pembelajaran Berasaskan Masalah (pp. 26-36). Proceedings of 2012 World Congress.

Nor Amalina, A. H., \& Zanaton, I. (2018). Pengetahuan, Kemahiran Pelaksanaan Dan Sikap Guru Terhadap Pembelajaran Berasaskan Masalah (PBM) Dalam Mata Pelajaran Sains (pp. 72-82). Seminar Antarabangsa Isu-Isu Pendidikan.

Norulbiah, N., \& Effandi, Z. (2016). Keupayaan pelajar dalam menjana masalah, menyelesaikan masalah matematik dan sikap pelajar terhadap penyelesaian masalah. Jurnal Pendidikan Matematik, 4, 1-16.

Nurhan, T., \& Meral, A. (2018). A Systematic Review of Flipped Classroom Studies in Turkish Education. International Journal of Social Sciences and Education Research, 4, 207-229. https://doi.org/10.24289/ijsser.405647

OECD (2018). The Future of Education and Skills: Education 2030. OECD Education 2030.

Phang, F. A., Abu, M. S., Ali, M. B., \& Salleh, S. (2014). Faktor penyumbang kepada kemerosotan penyertaan pelajar dalam aliran sains: Satu analisis sorotan tesis. Sains $\mathrm{Hu}-$ manika, 2, 63-78.

Piaget, J. (1964). Judgment and Reasoning in the Child. Paterson, NJ: Littlefield Adams.

Piaget, J. (1973). Psychology and Epistemology.

Reddy, M. V. B., \& Panacharoensawad, B. (2017). Students Problem-Solving Difficulties and Implications in Physics: An Empirical Study on Influencing Factors. Journal of Education and Practice, 8, 59-62.

Rian, V. (2015). Keberkesanan Modul BIOMIND Berasaskan PBM Untuk Meningkatkan Kemahiran Abad 21 dan Motivasi Serta Mengatasi Miskonsepsi Pelajar. Tesis Dr. Fal, Fakulti Pendidikan, Malaysia: Universiti Kebangsaan Malaysia.

Rosnaini, M., \& Norsiati, R. M. G. (2008). Pembangunan dan Penilaian Persian Kurses Multimedia Interaktif “Analisis Kualitatif Garam” dalam Subjek Kimia (pp. 527-541). 2nd International Malaysian Educational Technology Convention.

Saint, J., \& Robert, I. (1976). Cheating in Science. New Scientist, 72, 466-469.

Salih, C., Erol, T., \& Sacit, K. (2006). The Effects of Computer-Assisted Material on Students Cognitive Levels, Misconceptions and Attitudes towards Science. Computers \& Education, 46, 192-205. https://doi.org/10.1016/j.compedu.2004.07.008

Schwab, K. (2016). The Fourth Industrial Revolution: What It Means, How to Respond. https://www.weforum.org/agenda/2016/01/the-fourth-industrial-revolution-what-it-m eans-and-how-to-respond/ 
Sirakaya, A., \& Ozdemir, S. (2018). The Effect of a Flipped Classroom Model on Academic Achievement, Self-Directed Learning Readiness, Motivation and Retention. Malaysian Online Journal of Education Technology, 6, 76-91.

Siti Suhaila, S. (2015). Kesan Penggunaan Koswer multimedia animasi visual terhadap pencapaian pelajar dalam mata pelajaran Matematik. Laporan Projek Sarjana Pendidikan Teknikal (Rekabentuk Instruksional dan Teknologi). Malaysia: Fakulti Pendidikan Teknikal dan vokasional, Universiti Tun Hussein Onn. http://eprints.uthm.edu.my/7077/1/SITI_SUHAILA_BINTI_SUTAJI_24.pdf

Sriadhi (2015). Pembangunan Dan Penilaian Keberkesanan Koswer Multimedia Dalam Pembelajaran Tenaga Elektrik. Tesis Dr. Fal, Malaysia: Universiti Sains Malaysia.

Suhari, W., Suleiman, W. A., \& Saidin, Z. (2015). Flipped Classoom dalam Pengajaran Karangan (pp. 77-85). Seminar Bahasa Melayu 2015.

Sweller, J., Van Merriënboer, J., \& Paas, F. (1998). Cognitive Architecture and Instructional Design. Educational Psychology Review, 10, 251-296. https://doi.org/10.1023/A:1022193728205

Syafiq, H. (2018). Persediaan Kerajaan Menghadapai Revolusi Industri 4. https://kapital.my/2018/11/persediaan-kerajaan-menghadapai-revolusi-industri-4-0/

Tutuncu, N., \& Aksu, M. (2018). A Systematic Review of Flipped Classroom Studies in Turkish Education. International Journal of Social Science and Education Research, 4, 207-229. https://doi.org/10.24289/ijsser.405647

Wee, K. N. L. (2004). Jump Start Authentic Problem-Based Learning. London: Pearson Prentice Hall.

Wright, B. D., \& Stone, M. H. (1999). Measurement Essentials. Wilmington: Wide Range, Inc.

Zanariah, A. (2017). Pembangunan Modul Pedagogi Kelas Berbalik Berasaskan Pembelajaran Reflektif Untuk Politeknik Premier. Tesis Dr. Fasl, Kuala Lumpur: Fakulti Pendidikan Universiti Malaya, Kuala Lumpur.

Zuriawahida, Z. (2016). Keberkesanan Kaedah Pembelajaran Berasaskan Masalah Dalam Meningkatkan Kemahiran Berfikir Aras Tinggi Dan Menyelesaikan Masalah Dalam Kalangan Pelajar. Disertasi Sarjana, Fakulti Pendidikan Teknikal dan Vokasional, Johor, Malaysia: Universiti Tun Hussein Onn. 